\title{
Troubling the family: Coming out as lesbian and gay
}

Authors:

Petra Nordqvist, University of Manchester ( $1^{\text {st }}$ author $)$

Petra.Nordqvist@Manchester.ac.uk

The Morgan Centre for the Study of Relationships and Personal Life/ Division of Sociology

School of Social Sciences

Arthur Lewis Building

University of Manchester

Manchester, M13 9PL

01612750262

Carol Smart, University of Manchester ( $2^{\text {nd }}$ author)

Carol.Smart@Manchester.ac.uk

The Morgan Centre for the Study of Relationships and Personal Life/ Division of Sociology

School of Social Sciences

Arthur Lewis Building

University of Manchester

Manchester, M13 9PL

01612750262

Word count article: 8261 (including this page, abstract, references and acknowledgements)

Tables/figures: None 


\section{Abstract}

Legal and social attitudes towards gay men and lesbians have altered considerably in latter years and yet recent research suggests that 'coming out' as lesbian and gay may remain a troubled business, especially in one's own family. Exploring this theme, we situate gay and lesbian identities in wider family networks and explore how gay men and women negotiate family relationships at particular and significant moments in their lives, such as weddings and child birth. In doing so, we draw together three qualitative data sets; the Mass Observation Project and two interview studies exploring same sex commitment ceremonies and lesbian motherhood, all conducted in the UK in the 2000s. We investigate how hostility in families may shape the 'coming out' process and also how a culture of silence plays an important role in maintaining family relationships. We suggest that to understand what it means to 'come out' we need to examine the meaning of non-heterosexuality in the context of kin relationality and situate gay and lesbian lives in webs of intergenerational relationships.

\section{Keywords}

Childbirth, coming out, family, gay, lesbians, intergenerational relationships, same sex marriage 


\section{Introduction}

In the late 1960s and 1970s when the Gay Rights Movement was gathering strength and voice in Britain, there was a considerable political literature written on the daunting problems of coming out. Ken Plummer (1995) notes that although 'coming out' as gay or lesbian then became a historical, political and cultural possibility, generated, among other things, by the development of modern society, it often had severe personal consequences and many gay men and lesbians chose to remain 'in the closet' (Ponse 1976, Seidman 2002, Warren 1974). The associated problems of coming out were highlighted by the 'Outing' campaigns pursued by Peter Tatchell and any cultural shift towards favouring coming out were arguably impaired by the notorious Section 28 of the 1988 Local Government Act ${ }^{1}$ introduced by the Conservative Government.

With the repeal of Section 28 (in 2003) we have seen important changes taking place in Britain, both legally and socially. Not only has anti-discriminatory legislation been passed, but there have also been significant shifts towards protecting gay men and lesbians' right to a family life. The Civil Partnership Act 2004, for example, now recognises the commitment of same sex couples in law. Moreover, provisions have been made to secure gay men and lesbians' parental rights though the passing of the Adoption and Children Act 2002 and the revised Human Fertilisation and Embryology Act 2008. These two statutes have significantly increased same sex couples' possibilities of securing legal parenthood. Alongside these changes we have also seen significant social developments. Jeffrey Weeks writes in The World We Have Won (2007) that 'we are living [...] in the midst of a long, unfinished but profound revolution that has transformed the possibilities of living sexual diversity and creating intimate lives' (2007: x). Exploring the social, cultural and legal developments of 
gay and lesbian lives from 1945 onwards he suggests that the heterosexual/homosexual binary has been radically altered:

The sharp binary schism between [heterosexuality and homosexuality] that has structured, defined and distorted our sexual regime for the past couple of centuries, and perhaps reached a peak with the final determined reassertion of what has been described as a 'heterosexual dictatorship' in the 1950s, is now profoundly undermined as gays and lesbians, bisexuals and transgendered people have not so much subverted the established order as lived as if their sexual difference did not, in the end, matter [.] (Weeks 2007: 9)

It would appear that with this radical shift taking place, same sex couples are now more able to live life openly, enjoy their socially approved rights to a family life, and perhaps even live as though sexual difference no longer mattered (see also e.g. Seidman 2002, Roseneil 2002).

Given this context, it is maybe surprising to find some indications that living life openly as a gay man and lesbian may remain a troubled business, especially in relation to one's family of origin. We came across these suggestions as a consequence of starting to work together on three separate data sets all of which focussed on negotiating wider family relationships as a gay man or lesbian. Whilst there were important positive accounts in these data of wider families being accepting and supportive of their gay and lesbian family members, thus easing the process of 'coming out', we were struck by a strong sub-theme emerging that gay men and lesbians were also seen as 'troubling' and troublesome to their families. A few studies (Almack 2008, Elwood 2000, Valentine et al. 2003, Weeks et al 2001, Yip 2004) have highlighted some of the ongoing struggles that gay men and lesbians experience in relation to coming out to their families and we felt that our data could add to these insights, not least because the desire to live lives as if 'sexual difference [does] not matter' has not yet been fully achieved. Our data do not support an argument that the majority of gay men and lesbian 
struggle with coming out to members of their families, or that a particular subsection of family members would be especially problematic, indeed, it is important to understand the compass of our data (which we explain below) because our evidence is more subtle than this. Our focus is to understand the dynamics of families where there are difficulties and conflicts so that we continue to appreciate the real difficulties that some gay men and lesbians still encounter in living their lives openly.

Our data are drawn from two separate interview-based studies, one on same sex marriage (hereafter the SSM study) and one on lesbians conceiving children together using donor conception (hereafter the CT study), and we combine these with material from written documents found in the archival data set the Mass Observation Project (hereafter the MOP). Thus our paper starts with a discussion of our data sets and the methodological problems (and advantages) of bringing together materials collected separately. We then discuss some of the theoretical issues involved in understanding the entwinement of social change, family relationalities and generational differences which outlines our analytical approach. This contextualises the stories gleaned from the data and is explicitly intended to provide a way of understanding intergenerational differences. We conclude by drawing the arguments together and situating the selected narratives in the context of social change and intergenerational networks of relationships. We suggest that these complexities in families may arise from the incongruity between personal and cultural biographies and eras of the family members involved. 


\section{Methodology: Working with three data sets}

\section{The Mass Observation Project}

The Mass Observation Archive is a documentary resource comprising both historical and contemporary writings collected over several decades from volunteer writers and diarists. The general aim of the Archive has been to collect the everyday observations and stories of ordinary lives lived in Britain. Panellists are recruited widely and write about their lives knowing that their contributions are used for social research. The Mass Observation Project has existed in its current form since 1981, and it is referred to as The Project to distinguish it from the broader Archive which contains more historical material collected in the 1930s and during the Second World War. The data that are now collected comprise mainly freely written responses to regular 'Directives' which are sets of short questions on a wide variety of topics. The MOP material we draw on here was generated in 2000 as part of a Directive on family life which asked the panellists to record their memories and experiences of gays and lesbians in their families ${ }^{2}$. It asked simply whether respondents knew if there were nonheterosexuals in their families and they were left to decide how to respond. One hundred and sixty eight women and fifty men (a total of 218) responded to the Directive as a whole but not all responded to this specific question and some wrote only very short replies. This means that the quality of the responses varies, although we do not suggest that short responses are less useful than long ones.

The panellists in 2000 were predominantly middle-class retired professionals and although some respondents reported having a background in manual work, it was not (and was never intended to be) a statistically representative sample. There were a few panellists in their twenties and thirties but the majority tended to be in retired age groups. The largest group of 
men for example were between 70-79 years old, and although women were slightly more evenly distributed in terms of age, the vast majority (86\%) were over 40 years old (Smart, 2009, 2011; Sheridan et al. 2000 for more details). Because the MOP data is not intended to serve as a survey, their value resides in the quality of the written accounts found there and the ways in which panellists are free to write about what matters to them in their everyday lives.

\section{The Same Sex Marriage Study}

The second study that we draw on (the SSM study) explored the reasons why lesbians and gay men in England wanted to marry in the era shortly before the introduction of Civil Partnership in 2005. In particular it focussed on how same sex couples involved their families of origin in their plans and ceremonies, as well as attitudes towards legal and cultural change. It was carried out by Carol Smart, Jennifer Mason and Beccy Shipman from 2003-2006. It comprised 54 qualitative, in-depth interviews in total, 37 with couples and 17 with individuals. Of the 37 couple interviews 27 were conducted with lesbian couples and 10 with gay male couples. The 17 solo interviews comprised seven lesbians and 10 gay men. The majority of the interviewees were between 30 and 49 years of age and some couples had been together for as long as thirty years. All except one respondent described him or herself as white (mainly white British or white English) and the sample was disproportionately 'middle class' (a ratio of 8:1) taking into account factors of education level, the nature of employment and housing tenure. (Shipman and Smart, 2007; Smart 2007, 2008)

\section{The Conceiving Together Study}

The CT study comprised qualitative interviews with lesbian couples pursuing parenthood through donor conception in England and Wales and was carried out by Nordqvist from 2006-2009. The core focus of the study was to trace the journeys that couples went on in the 
process of achieving a pregnancy together. Included in the study were discussions about the responses of families of origin to learning of the pregnancy or birth of a grandchild. The study comprised 25 in-depth semi-structured interviews with 45 women taking part in a total of 20 couple interviews and 5 individual interviews. The participants were between 23 and 56 years of age; the majority being in their mid thirties. They were predominantly white British and almost two thirds had an undergraduate degree. Using education as an indication of class, the study mainly tapped into the experiences of white, middle class lesbian couples. (For more details see e.g. Nordqvist 2011, 2012). Because this study was focussed on lesbians it means that we have fewer accounts from gay men compared with lesbians across the two interview studies and this unevenness is necessarily reflected in the accounts that follow.

\section{Bringing the studies together}

The SSM study and the CT study contained a great deal of material on what happens when couples inform their families of their intention to marry or to have children together. In both studies we found that telling kin, particularly parents, presented challenges for the couples. Although both studies contained positive stories about the process of telling, what was clear was that for many it remained troubled and troubling. It was often referred to as a second 'coming out' and our respondents often anticipated negative responses from kin. We were struck therefore by strong similarities across these two studies, especially the tendency for couples to say that their families tolerated their relationships but were upset once they realised that they were permanent and likely to become more socially visible through the birth of a child or through a public ceremony. It was this synchronicity which suggested to us that bringing the two studies together might be worthwhile.

However, these two studies had no information on intergenerational relationships from the standpoint of grandparents or other relatives themselves. Although our interviewees often 
spoke with great understanding about the issues their parents might have to deal with on being told of an imminent birth or wedding, we did not actually have the voices of these older family members. The MOP data were therefore able to fill this gap to an extent because the written accounts we found there were suggestive of how parents, grandparents and other relatives might perceive gay men or lesbians in their families. The MOP writings are treated here as a kind of 'proxy' for how the actual parents (or other kin) of our interviewees might have responded. This requires the reader to engage in an act of faith to some extent and, in order to trust us (and the data) sufficiently, we feel it is important to explain how we came to include this rather different data set.

MOP data is unique because writers are encouraged to write from personal experience and they are invited to see their activities as a laying down of history for future researchers. They are anonymous, and many in 2000 had been writing for the Archive for a long time. This means that what became apparent in reading their accounts is that respondents did not feel constrained by either political correctness or by embarrassment in composing their replies. Of course, those who may have felt thus constrained would not have replied - but this is no different to any other piece of social research which depends upon voluntary participation. Panellists therefore wrote about such issues as love, shame, disgust, pity, horror, indifference. The whole gamut of responses can be found in these writings. However, we focus on the more negative end of the remarks here because in the process of bringing the studies together, we could map what some of the MO panellists were writing into the accounts of our interviewees. So, for example, spoken comments about being disinherited chimed with written comments about leaving certain people out of wills. Equally, spoken comments about not inviting parents to the wedding, chimed with written comments about children or relatives who were never spoken of in families. In this way, the three data sets 'spoke' to each other 
and issues raised in one place echoed around the other narratives, giving a fuller picture of the nature of these relationships.

It is important to note, however, that there are challenges and limitations inherent in using three different data sets. The studies were carried out in different contexts and were also different in scope, sample, researchers and data collection practices (although the two interview studies used the same qualitative logic and mode of analysis). The three sets were produced in the first decade of the 2000s and were therefore located at slightly different moments on an arc of social change in the UK, with the MOP data predating some important legal changes. They were also guided by different research questions and utilised different qualitative methods. For example, the two interview studies recruited gay men and lesbians with the specific view of exploring couple commitment and lesbian conception. In contrast, the MOP involved an established panel of writers who were recruited by the MOP to act as a panellist for the Project at large; these writers may or may not have agreed to respond to a specific study on gay men and lesbians in the family. These different processes therefore approached respondents in dissimilar ways, yet the stories that were collected in each study were not dramatically different which suggests a degree of commonality of experience. Had one set of respondents been drawn from a strictly religious group, or had one been a political group of gay or lesbian activists, then bringing their accounts together would have been much more problematic. But here we have essentially three samples drawn from White, middle class, professional and (fairly) secular England in the 2000s. Finally, it is hard to know whether interviewing people in person produces very different kinds of responses to asking people to write in a free and (relatively) unguided way about a given topic. Respondents may, for example, be more willing to voice unfavourable views in written accounts compared with 
face-to-face interaction, but we cannot know this for sure (McGhee and Harrison 2003, Smart 2011).

Whilst it is important to appreciate these limitations and drawbacks, we argue that there are considerable advantages to be gained by bringing the data sets together and that doing so may not be as methodologically unorthodox as it might appear. Reusing archival data, and bringing together different sets, is a well established practice in historical research, and this has also made its way into sociological studies (e.g. Savage 2007). Moore (2007), making the case for archiving and for reusing archived, qualitative data, challenges assumptions about the meaning of time, reflexivity and context that often underscore arguments against reuse. Her case is that the interpretation of meaning is not the sole prerogative of those who design the original study and that qualitative data is not frozen in time and place, but can have significance beyond its original context. Drawing on these arguments we suggest that the advantages of bringing together these studies are significant, particularly because these data sets are so rich and unusual. Strong themes emerged across the studies which meant that they were able to address each other intelligibly and thus provide an uncommon and significant insight into the workings of family life. By exploring the resonances we felt we had discovered through our familiarity with these separate studies we are able to generate insights into profoundly subtle and yet extremely significant processes of family life.

\section{Family, relationality and social change}

Jeffrey Weeks (2007) has provided a theoretical model for understanding the interweaving of socio-cultural change, gay identity and personal biography in contemporary Britain. $\mathrm{He}$ paints a picture of the decades following his birth in the mid 1940s and his formative years in the Gay Liberation Movement of the 1960s and 70s, and he situates his personal memories 
and his own experiences in specific historical time. This approach, sometimes referred to as the biographical turn, (Bertaux 1981, Plummer 2001, Chamberlayne et al 2000) brings personal experiences into sociological relief and the course of an individual life can become a lens through which to understand larger social and cultural changes. Weeks' account gives a strong flavour of what it was like to grow up gay (not a word that was used in this way in the 1950s of course) in the Valleys in Wales. His childhood years were in the repressive preWolfenden Report (1957) period and during most of his youth homosexuality was criminalised. Using this approach it becomes possible to see how individuals come to be framed by these historical eras, while not being determined by them. Generations born in Britain in the 1920s or 1930s would have been swathed in very hostile cultural attitudes towards homosexuality and lesbianism. Their personal life trajectories would have been very different to that of Weeks' (in the 1950s) and still more removed from generations born in the 1970s and 1980s. They lived much of their lives in a social and historical time when there would have been no positive images of same-sex relationships; rather homosexuality was formulated as a personal sexual perversion at best or an immoral criminal act against society at worst (Weeks 1981). This does not mean that older generations are, ipso facto, unfailingly homophobic but it does mean that they have very different reference points and cultural expectations compared with later generations.

The juxtaposition of such different generational life experiences means that grasping the unfolding of social change within family life is complex because families may contain three or four generations, each of which has lived their formative years during different personal and historical eras. Different generations in families are therefore grounded in different periods while also being tangled together in the present by ties of blood and affinity. The interplay between change and continuity across historical time can therefore result in 
ambivalences and tensions in intergenerational kinship relationships (Bertaux and Thompson 2007, Brannen et al 2004: 179). These tensions are likely to become part of the way in which families negotiate co-existence in interconnected webs of relationships. Put simply this means that generations can co-exist only if differences of values or ethics are either resolved or metaphorically shelved. In their study of intergenerational family life, Finch and Mason (1993) explored precisely this process and revealed the way in which families negotiate such tensions. They suggested that families operate through both explicit discussions and also nondiscussions. This insight is useful for understanding the place and significance of compromises that are only implicitly agreed. Non-discussion might be a way of managing and maintaining smooth family relationships while openness might challenge concord and bring strong disagreements back into play. For our exploration of coming out to family members, the idea that generational ties and affections can be sustained only if implicit agreements are adhered to, is a central theme. Of course generational difference and family relationships are also shaped by broader formations of gender, class and ethnicity (e.g. Kehily and Thomson 2011, Allan 1996, Frankenberg 1993), but our focus here is on the intersection of generation, family relationality and non-heterosexual identities. The importance of exploring this interaction and its dynamics in its own right emerged as we started to note how complex the process of negotiating openly both gay and lesbian identities was in family networks, and that similarities appeared to emerge across the data sets.

In what follows we discuss these themes in four subsections. The first explores how the anticipation of hostility can influence whether or not same sex couples are open about their lives. The second explores experiences of open hostility in relation to wider networks of kin. The third looks at the working of silence, while the final section examines how openness demands personal change. We conclude by returning to the ideas of Jeffrey Weeks. 


\section{Anticipating hostility}

I have not even told [my parents] that we are going to have a ceremony.[...] I think it will be better if they do not come because if they do come they will be really like disappointed that this is what their daughter has decided to do. (Erin, 23, SSM Study) I would like [my father] to know that I am happy and I have got somebody special in my life but he is a very religious man. And I do not think it would go down very well. (Theresa, 31, SSM)

These two quotations capture one of the main issues we seek to highlight in this paper, namely avoidance of difficult subjects in families. Erin and Teresa 'might' have been wrong about the reception they would have received since we know from other accounts that parents can and do change. However, this is not the point. Rather what is shown here is how the anticipation of disappointment or rejection guides the kind of interactions that go on in families.

One powerful example of such anticipated hostility regarded the issue of wills and disinheritance, and the risks that gay men and lesbians felt loomed in declaring relationships openly. Sometimes adult children anticipated severe reactions from older relatives if they 'came out':

Ray : The only people that we have not told are your parents.

Daniel: I just think that they would disinherit me [...] (Daniel 50, and Ray, 60, SSM)

The issue of disinheritance was echoed in one of the written accounts in the MOP data.

'One of my wife's sisters has a nephew by marriage that is queer. I do not think it bothers her at all but the young man's grandparents are not at all pleased. Grandfather and the boy's uncle were notorious womanisers so they are baffled by the boy's sexual preference. The old couple are quite well off and have drafted their will to 
exclude the gay grandson. To them it would be a waste of their inheritance. I can see what they mean.' (H 1543 M, married, 70 retired)

This passage contains an interesting and quite complex range of reactions and, of course, terminology. The use of the word 'queer' is quite unapologetic and although the term has been reclaimed in such a way that it now has a positive, transformative meaning, it seems unlikely that this is how it is being used here. In the same sentence we learn that the young man's mother is 'not bothered' about his sexual orientation, but that his grandparents are. What is more, the grandfather and uncle's strong heterosexual identity is conjured up by reference to his womanising which presumable is used here as a reference to family lineage and to signal being unpleasantly surprised at finding a man in the family displaying a identity seen as different to theirs. The gay grandson is to be disinherited because to leave money to him would be a waste. It is not entirely clear what is meant by this, but presumably it refers to the fact that the family line will not be carried on; the young man is seen as a kind of genetic dead end. Finally the writer aligns himself with the grandparents thus giving firm approval to the policy of excluding members of the family who are homosexual from inheritance. This is, we suggest, a powerful passage because it expresses so candidly a distaste for a family member simply because of their sexual orientation. It is not hard to imagine what family gatherings might be like if $\mathrm{H}$ were present in the company of the gay grandson. The young man would undoubtedly feel the hostility even if it was not put clearly into words in his presence. Little wonder therefore that Daniel (above) might genuinely fear disinheritance if his parents learnt about his wedding plans since it is clear that some families do still think in these terms.

As we have acknowledged above, not all the MOP accounts were hostile or homophobic, and we provide some examples of this below. However, one of the more interesting reactions 
to the question about whether there were gays ${ }^{3}$ or lesbians in the family was the hostile rejection of the idea that such a thing could be possible in respectable families. This denial is important because it reflects the cultural milieu of certain families and provides an insight into precisely how difficult it might be to raise the issue, let alone come out as gay or lesbian. In a context where one's sexual orientation is simply inconceivable, it seems appropriate to anticipate hostility should the news be revealed:

As far as I know, we haven't any in our families. [...] I find such relationships repulsive. (C1939 Female, 66)

To the best of my knowledge we have no homosexuals in our family. That's the way it should be. (D666 Female, 80)

I have bothered to make a contribution to this directive because, to my knowledge, there are no active homosexuals in any of my remotest members of my extended family. It might be of some interest to researchers to know that there are families who are fortunate enough not have these problems. (H1806 Male, 75

So, living life openly as a gay man or lesbian could be experienced as a very risky process in certain families. From the point of view of gay men and lesbians it is enough to believe that a relative may hold unfavourable views for it to structure the 'coming out' process. Indeed the belief may be just as significant as knowing with certainty. However, most of the gay men and lesbians we interviewed had told their families of origin about their sexuality and also about their plans to marry or have children and so, in the next subsection, we turn to actual experiences rather than anticipated experience.

\section{Open hostility and wider family relationships}

The women who participated in the Conceiving Together Study were not in a position to conceal their situation from family members unless they lived a long way away and/or had cut all contact. So whereas it was possible for some in the SSM study to hide their weddings 
from hostile relatives, the birth of a child put these lesbian relationships into the public domain in irrevocable ways (Almack 2006). Announcing the birth of a child was quite traumatic for some of the lesbians in the study and was sometimes experienced as a second 'coming out'. In Lydia's case (below) she was forewarned of problems because her mother appeared to accept her lesbianism only if it meant she would never become a mother herself:

When I came out to my mum when I was 19, the very first thing she said, literally, was 'I hope you won't have children'. [...] So it kind of stuck with me. [...] I told my mum on the phone [when I was four months pregnant] and she said ' $O$, I'll have to think about that and call you back'. That's what she said. What was there to think about when I was four months pregnant? (Lydia, 33, CT Study)

What seems to be evident in this exchange is a reflection of wider social values where a different sexual orientation is tolerated because it is a private matter between adults, but where becoming a parent is a step too far. Lydia's mother was perhaps reflecting the (recent) views of politicians and others who were hostile for a long time to the idea that same sex couples should be allowed to adopt. Although 'single' lesbians or gay men were approved for adoption it was thought quite inappropriate to introduce a child into a same-sex household where he or she would witness an ongoing relationship. What is apparent here is that coming out as gay or lesbian is only the first step towards being able to live a life as if sexual orientation does not matter.

Another example of this problem was the case of Emma who had suffered a very hostile response from her parents when she first came out. She had worked hard to rebuild the relationship with them, but having a child meant going through the whole process again. Emma's parents had not told friends and relatives about Emma's sexuality or about her relationship with her partner Hannah. However, once Emma gave birth an explanation was 
required and Hannah's presence became a problem for the story her parents wanted to construct. So her parents created a fiction for the wider family about Emma's relationship.

Emma's parents have told all their family that Emma's with a man living in [City]. So, yes, he's called John. He's an engineer and there's this whole story is going on and they're adamant that they're not going to go back on that story. [...] They know exactly what the truth is, but they're choosing not to tell it. (Hannah, 23, CT Study)

This account reveals not only the difficulty that Emma's parents had in accepting her sexuality and how she wanted to live her life, but also brings into perspective the significance of the wider family. Thus parents and children co-exist within networks of relationships in which they are embedded. Their lives are 'linked' together within and across generations (Bengtson et al. 2002). This means that a hostile response from parents may ripple through the whole extended family causing a range of unforeseen or undesirable consequences. This was illustrated in one account in the MOP data where a woman reflected on the fact that her cousin was in a same sex relationship. The cousin's father had reacted with outrage, and this in turn affected the entire network of relationships:

I knew her father had taken it very badly [when his daughter started a relationship with a woman] and for several years refused to speak to her - or about her to others. This was very distressing for the rest of the family, especially the older generation, who although they didn't really understand about 'B's 'new' sexuality, wanted to go on as before, and her father's behaviour made this very difficult. (C2844 Female, 40, original emphases)

Parents therefore can block relationships with other family members and can put obstacles in the way of openness by framing the issues in particular ways or even by creating complete fictions about their gay or lesbian children. Gay or lesbian lives may thus be perceived to potentially destabilise whole networks of relationships simply by being open. 


\section{The working of silence: Maintaining family relationships}

These issues raise the question of how parents and adult children can maintain relationships when gay and lesbian lives have the potential to be so destabilising for some families. What emerged across the three studies was that people manage this dilemma by dealing with gay or lesbian identities through avoidance, silence or non-discussion. In some instances this would go as far the de-kinning of embarrassing relatives, which is to say that they were completely disavowed (Konrad 2005). For example, several of the MOP respondents noted:

I know of only one such person, the son of one of my husband's cousins. [...] He came out and lives, I believe with an interior designer. The family do not talk about him. (R1760 Female, age unknown)

'Of course there's my husband's Uncle T. whom I've never met [...] The Uncle T. in question was very well dressed, and theatrical and was 'sent away to America', so the only conclusion to be drawn was that he was gay. And although there were lots of whispers, nobody ever actually mentioned the word homosexual. (A1706 Female, 54)

Finch and Mason (1993) suggest that non-discussion forms a salient part of how families negotiate their relationships, and this was a strong theme in the MOP replies where statements about 'sweeping things under the carpet' were common. Ponse (1976) argues specifically that silence about gay and lesbian identities enables families to maintain a flow of interaction and that silence smoothes over issues which could potentially disrupt social expectations and generate conflict. A sexual identity which is only hinted at but not confirmed is not 'really known' and therefore remains open to negotiation and interpretation, as well as denial. And so Ponse suggests that families enter into tacit agreements not to openly discuss or make explicit knowledge about a member's gay or lesbian identity in order to preserve family relationships. Silence allows relationships to continue because hostile views remain unspoken. 
The only out gay relative I have or had was an older cousin of my Dad's who lived in Brighton. Although everyone in the family knew he was gay, nobody ever discussed it so it wasn't really an issue, positive or negative. (I2872 Female, 33)

For gay men and lesbians this meant that they negotiated their personal lives through discretion. This is not a new discovery (Ponse 1976, Warren 1974, Weston 1991), but what might be surprising is how such a culture remains so powerful in the context of family life in the 2000s. Put together these three studies indicate that non-disclosure provides a means through which gay men and lesbians are able to negotiate a form of acceptance by their families. Many chose not to 'confront' their family members openly, and endured relationships with siblings, parents and relatives which were based on tacit agreements not to mention their sexuality. For example, Miriam from the SSM study noted:

I am sure all our family know [that we are a couple] but we have never actually come out and said to anybody [...] to the older ones we have never said it outright. Although when we go up to visit relatives they always give us a room and a double bed together [...]. So we just don't speak about it, it is just seen you know. (Miriam, 59)

A MOP panellist, herself a lesbian, stated that she had never discussed her sexuality with her parents although she has been with the same partner for 30 years.

I never discussed the matter with any of my family. [...] I don't think they would have been pleased. They may have guessed, and preferred not to talk about it. (B1665 Female, 66)

\section{Open declarations - renegotiating relationships?}

Many gay men and lesbians in our interview studies did however decide to break the silence and face the risks involved. In a family culture of discretion and avoidance this meant challenging long established ways of relating. Valentine et al. (2003) note that a reworking of family relationships is required to live openly as a gay man or lesbian and in our interviews we found that this was often very hard. Lorrain's account from the SSM study is illustrative: 
The people that baffled me more than anything was [my partner's] eldest brother and his wife and family and I mean I had always got on remarkably well with them and there was no animosity or anything there. And we sent them an invite [to the wedding] and [...] the eldest brother he never even replied [...] I just found that really bizarre it was as though he did not acknowledge it at all. [...] I just find that very weird.

(Lorraine, 34)

Other family relationships were reworked successfully to encompass a more open acceptance of the gay or lesbian relationship but it is clear that the process could be difficult for everyone involved. A female panellist from the MOP data reflected:

My son and one of my grandsons are gay. It was a job to come to terms with it in the beginning, especially my son. But my love for him overcame any doubts as to whether I would disown him or not. (B1424 Female, 76)

It seems that a similar ambivalence emerges from Frank's account:

[My parents] could not quite bring themselves to do the wedding card thing, [instead they sent] a picture of cats 'To Boris, Frank, Tabby and Wes with special wishes for [the day]' and 'love from Ma and Pa'. (Frank, 39, with Wes, 38, SSM)

Parents, children and other extended family members may come to accept same sex relationships once any initial upset, shock and disappointment has been worked through. But even in these ultimately supportive families, couples will have gone through a preliminary process of renegotiating relationships in order to be openly accepted in the family. In such cases we found that a wedding ceremony or a pregnancy could, in itself, play an important role in turning uneasy family relationships into more accepting ones (Shipman and Smart 2007). For example, Audrey and Jen from the SSM study noted:

Jen: [My mum was] very disappointed and this is why the wedding was so important for us 'cos it was also saying to my family that this was a lifestyle choice, it wasn't just a fad. [...] 
Audrey: Yeah, and also making her understand that this is serious [...] this isn't something that is going to change. [...] It worked; it's made a huge difference. (Jen, 38 and Audrey, 47, SSM)

The point that is made by these accounts is that no matter what the outcome, all of these couples had an obstacle to overcome. A wedding or birth announcement from a same-sex couple is still a risky matter where families are concerned. Even though they may become a cause for celebration, it is also possible that they will provoke hostility and a worsening of relationships. This is the cloud that same sex couples live under still and it is important understand why this cloud lingers so tenaciously, even where families are loving and where social attitudes in general are changing rapidly.

\section{Conclusion}

Our starting point for this paper was the paradox that although there have been major legislative reforms in England and Wales to end discrimination against gay men and lesbians, families may still be hostile towards close kin who are homosexual. We have acknowledged that there are many intersecting reasons for this, such as religious belief and differences of gender, social class and education. However, our focus has been on the more detailed canvass of intergenerational relationships and how they unfold in practice in everyday family life. We do not suggest that this alone provides a full explanation for the slowness of change in some families, but our focus on interpersonal relationships sheds sociological light on the problems that people may continue to endure privately. It also helps to explain why, notwithstanding the difficulties and even downright unpleasantness to be found in some families, many couples strive to keep their family relationships alive. Focussing on what goes on between people in intimate/family relationships injects another dimension into an analysis of how 
change unfolds in uneven ways. It also throws light on why coming out remain an issue in the lives of gay men and lesbians.

We argue also that it is important to understand sociologically the diverse life experiences of the different generations who co-exist in families. These generations may identify as being members of the same family, yet inhabit quite different cultural and experiential 'worlds'. This returns us to Jeffrey Weeks and the challenge of incorporating an understanding of the different biographies of different generations. While we do not suggest that each generation is inflexibly set into a set of dominant values which prevail at a given time (Bertaux and Thompson 2007, Brannen et al 2004), or that hostility or ambivalence is necessarily located in one particular generation, we argue that changing deep-seated understandings and expectations which are historically established as part of a formative process of the self, may not be easy. Thus it is important to understand why the (grand)parents of gay or lesbian (grand)children who grew up when homosexuality was a crime, have to go through a period of adjustment when faced with civil partnership and lesbian motherhood. It helps to explain why the MOP respondent who was born in 1924 (B1424, above) considered disowning her gay son because this would have been the culturally accepted thing to do for her generation. She was able to reject this option, however, in favour of keeping her relationship with him because she put love above convention. So she was not over-determined by her generational biography, yet she clearly had to deal with it and take a stand against it. For other parents and relatives the balance went the other way, while yet others could only cope by ignoring it all.

Thus we argue that different family members may carry on different generational traditions which make them adjust to personal change in different ways. The cultural values they internalised biographically are part of the very constitution of the self since they permeate deeply through language, actions and images. This means that accepting change can be very 
hard as it involves a reassessment of the self rather than just accepting a new element into one's life. To imagine that people can easily shed values forged in a very different cultural past is therefore perhaps naive. This also helps explain why many families still resort to negotiating non-heterosexuality through non-discussion. Hostility and ambivalence towards gays and lesbians can ripple through family relationships so that what is at stake is a whole network of family relations. Silence functions to maintain networks across personal biographies and social change. Tacit agreements, however, mean that bringing gay and lesbian relationships into the open, through civil partnerships or parenthood for example, can become very difficult because they may challenge the relational status quo of vital networks. The insights generated in this paper do not challenge Weeks' (2007) broad thesis on the important social and legal improvements that have been achieved in the lives of lesbians and gay men, but they do go some way to explain why not everyone yet finds it straightforward or untroubling to live non-heterosexual lives.

\section{Notes}

${ }^{1}$ Section 28 was introduced as part of the Local Government Act 1988 and banned the 'promotion of homosexuality' by local authorities.

${ }^{2}$ Dorothy Sheridan, the former Chief Archivist of the Mass Observation Project, sent out the Directives to the panellists three times a year. In 2000 the Directive had a section on family life, a section on family secrets, and another section on gays and lesbians in the family which was commissioned by Professor Derek McGhee of Southampton University.

\footnotetext{
${ }^{3}$ The Directive used these words and so we reproduce them accurately here.
} 


\section{Acknowledgements}

Our thanks go to the anonymous reviewers for most helpful comments and suggestions. The Mass Observation material is reproduced with the kind permission of the Trustees of the Mass Observation Archive, University of Sussex. Both the interview studies were funded by the Economic and Social Research Council UK. 'Same Sex Marriage' was a research grant reference RES-000-23-0418 and 'Conceiving Together' was a doctoral award reference PTA031-2006-00503.

\section{References}

Allan, G (1996) Kinship and Friendship in Modern Britain, Oxford: Oxford University Press.

Almack, K. (2006) 'Seeking sperm: Accounts of lesbian couples' reproductive decisionmaking and understandings of the needs of the child', International Journal of Law, Policy and Family, 20(1):1-22

Almack, K. (2008) 'Display work: Lesbian parent couples and their families of origin negotiating new kin relationships', Sociology, 42(6):1183-1199

Bertaux, D. (1981) (ed) Biography and Society: The Life History Approach in the Social Sciences, London: Sage

Bertaux, D. and Thompson, P. (2007) 'Introduction' in Bertaux, D and Thompson, P. (eds) Between Generations: Family Models, Myths and Memories. Second edition. London: Transaction Publishers.

Brannen, J., Moss, P and Mooney, A. (2004) Working and Caring over the Twentieth Century: Change and Continuity in Four-Generation Families, Basingstoke: Palgrave Macmillan. 
Chamberlayne, P., Bornat, J. and Wengraf, T. (2000) The Turn to Biographical Methods in Social Science, London: Routledge

Davies, P. (1992) ‘The role of disclosure in coming out among gay men' in Plummer, K. (ed) Modern Homosexualities: Fragments of Lesbian and Gay Experience. London: Routledge.

Elwood, S. (2000) 'Lesbian living spaces: Multiple meanings of home, Journal of Lesbian Studies, 4(1):11-27

Finch, J. and Mason, J. (1993) Negotiating Family Responsibilities, London: Tavistock/Routledge

Frankenberg, R. (1993) White Women, Race Matters. The Social Construction of Whiteness. London: Routledge.

Giddens, A. (1991) Modernity and Self Identity, Self and Society in the Late Modern Age, Oxford: Polity Press.

Haimes, E. and Weiner, K. (2000) “"Everybody’s got a dad...”. Issues for lesbian families in the management of donor insemination', Sociology of Health and Illness, 22(4):477-499

Kehily, M. and Thomson, R. (2011) Figuring Families: Generation, Situation and Narrative in Contemporary Mothering, Sociological Research Online, 16(4)

Konrad, M. (2005) Nameless Relations, Oxford: Berghahn Books

McGhee, D. and Harrison K. (2003) 'Reading and Writing Family Secrets', Auto/biography 11(1-2): $25-36$

Moore, N. (2007) ‘(Re)Using Qualitative Data?’, Sociological Research Online, 12:3

Nordqvist, P. (2011) 'Choreographies of sperm donations: Dilemmas of intimacy in lesbian couple donor conception', Social Science and Medicine, 73(11): 1661-1668 
Nordqvist, P. (2012) 'II don't want us to stand out more than we already do': Complexities and negotiations in lesbian couples' accounts of becoming a family through donor conception', Sexualities, 15(5-6): 644-661

Plummer, K. (1995) Telling Sexual Stories, London: Routledge

Plummer, K. (2001) Documents of Life 2, London: Sage

Ponse, B. (1976) 'Secrecy in the lesbian world', Journal of Contemporary Ethnography, 5(3): $313-338$

Robinson, P. (2008) The Changing World of Gay Men. Palgrave Macmillan: Houndsmill Roseneil, S. (2002) 'The heterosexual/homosexual binary. Past, present and future', pp. 27 44 in D. Richardson and S. Seidman (ed) Handbook of Lesbian and Gay Studies. London: Sage.

Savage, M. (2007) 'Changing Social Class Identities in Post-War Britain: Perspectives from Mass-Observation', Sociological Research Online, 12(3)

Seidman, S. (2002) Beyond the Closet. The Transformation of Gay and Lesbian Life. London: Routledge

Shipman, B. and Smart, C. (2007) “"It's made a huge difference”: Recognition, Rights and the Personal Significance of Civil Partnership', Sociological Research Online, 22(1): January

Smart, C. (2007) 'Same Sex Couples and Marriage: Negotiating relational landscapes with families and friends', The Sociological Review, 55(4): 687-702

Smart, C. (2008) “"Can I Be Bridesmaid?”: Combining the Personal and Political in SameSex Weddings', Sexualities, 11(6) 761-776 
Smart, C. (2009) 'Family Secrets: law and understandings of openness in everyday relationships' Journal of Social Policy 2009, 38(4): 551-567

Smart, C. (2011) 'Families, Secrets and Memories', Sociology, 2011, 45(4): 1-19

Valentine, G., Skelton, T. and Butler, R (2003) 'Coming out and outcomes: Negotiation lesbian and gay identities with, and in, the family', Environment and Planning D: Society and Space, 21 (4): 479-499

Warren, C.A.B (1974) Identity and Community in the Gay World, New York: Wiley

Weeks, J. (1981) Sex, Politics and Society: The regulation of sexuality since 1800. Harlow, Essex: Longman

Weeks, J. (2007) The World We Have Won. London: Routledge

Weeks, J. et al. (2001) Same Sex Intimacies: Families of Choice and Other Life Experiments. New York: Routledge.

Weston, K. (1991) Families We Choose: Lesbians, Gays, Kinship, New York: Columbia University Press.

Yip, A.K.T. (2004) 'Negotiating space with family and kin in identity construction: The narratives of British non-heterosexual Muslims', The Sociological Review, 52(3): $336-49$ 